\title{
The Identity and Socio-cultural Processes in the Migrant Communities of Tatarstan
}

\section{Tatiana Titova}

PhD, Doctor in History, Full Professor, Kazan (Volga region) Federal University; tatiana.titova@rambler.ru

Elena Frolova

PhD in History, Associate Professor, Kazan (Volga region) Federal University; elenaieup@mail.ru

\section{Guzel Stolyarova}

PhD, Doctor in History, Full Professor, Kazan (Volga region) Federal University; guzelstol@mail.ru

Doi:10.5901/mjss.2015.v6n6s5p269

\begin{abstract}
The relevance of the problem under research is explained by the necessity of studying the problems connected with the adaptation of labor migrants in the host society, which is of social, economic, political and cultural significance for the modern Russian society in general, and the Republic of Tatarstan in particular. The necessity of studying the adaptation strategies of migrants in the host society, as well as socio-cultural processes inside migrant communities is growing. The purpose of the research is to analyze the structure of identity and socio-cultural processes in the environment of migrant communities in the Republic of Tatarstan. The analyzed materials were prepared using the methods of mass poll, as well as biographical and semi-structured interview. As a result of the systematization of the data the structure of the social identity of migrants was analyzed. The linguocultural competence in relation to Russian and Tatar languages was examined, the most updated ethnoconsolidated signs were revealed. Special attention was paid to the analysis of religion as an important component of ethnic integration. There was made a conclusion that the socio-cultural orientations of migrants made an impact on the character of their social contacts and successful adaptation in the host society.
\end{abstract}

Keywords: migration, social identity, ethnic and cultural practices of ethnic identity, adaptation.

\section{Introduction}

\subsection{The relevance of research}

Labour migration is of exceptional economic, social, political and cultural significance in the modern world. Transport accessibility, the development of capitalist relations and opened borders - these are the conditions to make freedom of movement possible. Today, labor migration is one of the main channels of social mobility. Migration processes occupy a central position on the agenda of public policy, media, and academic symposiums. Migration has become not only a part of the daily and professional lives of people, but also established a wide range of exciting and problematic issues, the study and the solution of which seems to be promising.

\subsection{The review of research on the topic}

Representatives of various social sciences study the problems of labor migration. Demographers are interested in the contribution of migration to the demographic processes (reproduction and the overall growth of the population) and the change in the structure of the population and its characteristics (aging, gender balance, life expectancy, the structure of diseases, etc.) (Chudinovskikh, 2004). Most of the migrants belong to the category of the working population and play a significant role in the filling of labor market with human resources. In this regard, professional, age and gender aspects of migration are of great interest to economists. The subject of economic analysis is the contribution of migrants to the GDP of countries of origin and host countries, the direction of movement of workers (to the Russian Federation, to the foreign countries, internal migration), the transformation of economic sectors, which employ a significant number of migrants, and economic mechanisms of the migration regulation (Abashin, 2007-2008). Studies of migrant practices are under the 
interest of anthropologists and sociologists. Primarily the analysis focuses on the internal and external factors of migration (the so-called push- and pull- factors). The authors refer to the mechanisms of migration - how people choose the strategy of moving and duration of stay (short or long), what resources are needed to move, which communication channels are used to maintain links with their families and within the community (Titova et al. 2013). Considerable attention is paid to the issues of adaptation and characteristics of the host society - how high the level of xenophobia in countries where migrants go to work is; if there are any mechanisms of adaptation and integration of newcomers, etc. (Brednikova, 2003). At the same time, the study of life strategies of migrants in the regions of the Russian Federation requires closer examination.

\section{Methods of the Research}

\subsection{Theoretical and empirical methods}

The study is based on methodological principles of the multiparadigmatic approach, supplemented by certain provisions of the theory of nationalism (Gellner, 2009; Hobsbawn, 1983), socialization (Berger and Lukman, 1995), as well as the concept of "social organization of cultural difference" F. Barta (Barth, 1989).

The research is based on the analysis of empirical material, collected in 2014. Data was collected by means of a mass survey among representatives of the diaspora, observations and semi-structured biographical interviews. The submission of the resulting material is based on the principles of so-called «thick description», the option of analysis that is made in terms of the informants themselves.

\subsection{Base research}

During the survey 500 migrant workers among the Uzbek, Azerbaijani and Tajik population of the Republic of Tatarstan were interviewed. 20 interviews with the representatives of the diaspora were also conducted.

\section{Results and Discussion}

\subsection{Characteristics of the research object}

The total number of respondents included 150 Azerbaijanis, 150 Tajik, and 200 Uzbek. The ratio of male and female respondents distributed as follows: among the Azerbaijanis respondents $58 \%$ were men, $42 \%$ - women; among the Tajik $67 \%$ and $32.7 \%$ respectively; among the Uzbek - $70 \%$ and $30 \%$ respectively. Among the Tajik respondents young people under 25 years old (78.7\%) and young people aged from 26 to 35 years old (15.3\% of respondents) dominated. Among the Uzbek, the number of respondents under 25 years was 14\%, aged $26-35$ years - 44\%; $36-50$ years - 42\%. Among the Azerbaijanis $30 \%$ of the respondents were represented by people under 25 years old, $34 \%$ - aged $26-35$, and $30 \%$ - aged $36-50$ years.

\subsection{Social identity}

The research of the structure of social identity of respondents shows that the best relevance of ethnic identity, compared with other study groups was demonstrated by the Azerbaijanis. Answering the question: «Who am I?» two-thirds of the Azerbaijanis named their ethnicity. In a list of important social factors of identity, ethnic identity was on the second place, leaving behind family and gender characteristics. However, the majority of representatives of the Azerbaijani diaspora, are either natives of the Republic or lived there for more than 10 years, while a significant portion of Tajik and Uzbek respondents have lived in the country for less than 5 years.

In the structure of the social identity of the Uzbek respondents, status characteristics (as a person, a citizen, etc.) took the first place, the second place was gender and family roles, the third were professional characteristics. Ethnic identity was the last - it was mentioned by less than $5 \%$ of respondents.

When analyzing self-identifications of Tajik respondents, it was found out that the number of subjective characteristics in their identity matrix prevails over objective: the first place in the structure of subjective identity was given to personal characteristics (to be "kind", "beautiful", "intelligent", etc.) - it was mentioned by every second Tajik respondent. Professional and status characteristics are relevant for a quarter of respondents. Just like Uzbek respondents, we noted the importance of ethnic identity of less than $5 \%$ of Tajik respondents. 
The prevalence of subjective characteristics in the structure of social identity may indicate that respondents hardly perceive themselves in the context of social relationships and, consequently, are poorly integrated into the host society.

\subsection{Problems of the integration into the host society}

For the majority of those who made a decision to move to Tatarstan was the fact that Tatarstan is perceived in their own country as a Muslim republic. Informants say that it is generally comfortable inter-ethnic climate in the country: «We are fine in Tatarstan, not everywhere the situation is as good as here, our religion is the same" (male Tajik, born in 1980); «From the first day I felt that I got a second home, because Tatarstan and Azerbaijan have a lot in common. And also in Tatarstan there is a lot of common customs as Qurban Bayram, Uraza Bayram, Nowruz Bayram. And the wedding customs and funeral customs are the same. And I like this feeling of the second home. And here it is easy to work and live" (male Azerbaijani, born in 1972).

One-third of the respondents in all research groups approve that they experience difficulties in communication with local people. Tajiks and Uzbeks see the reasons for this in poor knowledge of their native language and national origin («They say different things - all people here think, that people arrived from Tajikistan are not educated, they are terrorists and drug traders» (male Tajik, born in 1962); and Azerbaijanis - in psychological characteristics of their own and the local population. The study of the attitudes towards migrant communities among the local population demonstrates that the population of the republic, justifying the negative attitude towards migrants, indicates the same reasons - the lack of knowledge of the language, unwillingness to adapt and the lack of knowledge about culture, traditions, peculiarities of the psychology and mentality of the indigenous population.

Respondents who have moved to the republic recently, noted that individualism of the local population and weak expression of the collectivist principles prevent their adaptation: «We do not have to name reasons why we go visiting. We've been friends with our neighbors. In our country people living in the same apartment house starting from the first and till the last floor - everyone knows each other. And here I do not know my neighbor, who lives next door. For example, when we prepare pilaf - we take it to our neighbors. And they look at us with surprise. This is an unpleasant surprise. This is a disadvantage, that the neighbors are not in contact with us» (male Tajik, born in 1992).

Responding to a question about the impression that a daily life of the local population have on them, several informants said some negative, in their opinion, characteristics. It is, first of all, lack of respect for parents, «In our country (Tajikistan) both - the Tatars and Tajiks are all welcoming. I have been at many holidays, Tatar wedding was fun. But I did not like attitude of children toward their parents. They believe that they are free, do not obey what their parents say. Speak roughly. We must respect our parents who raised us» (male Tajik, born in 1992).

At the same time, the two-thirds of Azerbaijanis and Uzbeks and every second Tajik noted that they have friends among the local population - mainly the Tatars»: «I feel closer to Tatars. The attitude of the Russian people towards foreigners is different. They communicate little, are not so hospitable. But Tatars are hospitable, they are easier to find the common language with» (male Tajik, born 1993).

In all the groups, respondents show a rather high level of intra-group cohesion, which is an indirect factor of the low degree of readiness for interethnic cooperation. The most concerned respondents are Azerbaijanis: almost all respondents, the two thirds of whom live in the cities of the Republic of Tatarstan for more than 10 years, and the third of them are native citizens of the Republic, emphasized that they maintain close ties with the representatives of their nationality in the city.

\subsection{Attitude to interethnic marriages}

The respondents clearly expressed their orientation on mononational marriages: «Even if you live in another country, it is undesirable "to mix blood", as well as our language, our traditions»; «There is an opinion that our nationality is above the others and the rest are the second-rate. And it is believed that it is better get married with your people than other people. And the Azerbaijanis have such a terrible tradition to marry their relatives» (male Azerbaijani, born in 1979).

The majority of respondents in all groups are in mononational marriage. Two-thirds of the Uzbeks, the third of Azerbaijanis, and one from each ten Tajiks said that a marriage of their relative with a representative of other nationality would be categorically disapproved. The most categorical position on this issue is taken by men and women from the age groups of 26-35 and 36-50 years old («We try to avoid marriages with local girls. My brothers, nephews, most of them are not married, they work here, and I'll do my best not to let them marry here. Their parents also asked me to control them so they will not find brides here» (male Uzbek, 37 years old). 


\subsection{Religion as a factor of solidarity}

Respondents believe that religion plays a significant role in making them united with other people of their own nationality. Two-thirds of respondents in all groups, answering the question: «What, in your opinion, unite you with people of your nationality?» noted the position «religion». One-fifth of interviewed Azerbaijanis and Tajiks, and every second Uzbek respondent took priority 1 and 2 from the list of identifying factors, giving the second position to the concepts such as «origin», «language», «culture».

Azerbaijanis respondents, who participated in a focus group, said that for the members of the diaspora, religion is not an important unifying factor: «for the Azerbaijani people traditions are more important than religion. Azerbaijanis do not really the follow the religion, they know (religious norms), go to the mosque, but they are not engaged in radical religious actions. They support Islam, but they do not go to the mosque every day. The aged might go, but not young people. They prefer to study science» (male Azerbaijani, born in 1972).

Most of the Azerbaijanis and Uzbek respondents have no difficulty in carrying out their religious lives; the third of young (under 25) Tajiks recognize that sometimes they experience some difficulties, mainly related to the subjective circumstances of life (education, work).

The number of respondents who feel the need for strict observance of religious precepts and practices is two-thirds among Azerbaijanis and Tajiks, and the third of the Uzbek respondents. There are 1.5 times more young people among them than in other age groups. However, the actual behavior of the respondents differ from the declared intentions.

The one-third of Tajiks and the one-fifth of Uzbek respondents regularly attend the mosque on Fridays; the vast majority of Azerbaijanis respondents approve that they attend the mosque on occasion, or because of the great need. One-third of Tajiks and a half of Uzbeks state that they do not go to a mosque or visit it extremely rarely. Also the vast majority of respondents in all groups answering whether they attend religious events and read any religious literature, answer negatively. The main reason for non-fulfillment of religious orders for priority of the respondents is their work («People mostly come here to earn money, we have no time to go to the mosque» (male Uzbek, born in 1959).

One-third of the Azerbaijanis and the Tajik have expressed a desire to make their own implementation of religious prescriptions and prohibitions; among Uzbeks a share of such respondents is insignificant. Supporters of strict religious practices among young people are twice more than in older age groups.

Respondents noted a number of factors that hinder their integration into the ummah of Tatarstan. For example, many informants regret that due to the lack of knowledge of Tatar language, they cannot fully understand sermons at the mosque: «All mosques in Tatarstan deliver their sermons in Tatar. Kul Sharif also. It's bad, because not everyone knows Tatar, I have Tatar friends who do not speak Tatar language "(female Tajik, 20 years old). The migrants with insufficient knowledge of Tatar language listen to the sermon only nominally. The Azerbaijanis respondents noted that for them visiting the mosque is purely religious in nature and is not a leisure activity: «They pray and leave - they don't stay there. In Azerbaijan, we don't have such practice - to stay in the mosque and talk. The mosque is used to pray and leave» (male Azerbaijani, born in 1950).

\subsection{The attitude to the role of religion in society}

The majority of respondents who participated in the study are aware of the fact that regulations of modern life can't be realized with the help of religious norms: «This is very bad, because the only way is impossible. Even if a train goes in one direction, it will never return. It's impossible. Only Christian direction can is not possible either. Islam only is also impossible. We are a multiethnic country. Buddhism, Christianity, other religions exist here. And if the religion is different the people are different. This doesn't work this way. If there is only Islam, it can not be above the others, there are Buddhists and Christians» (male Azerbaijani, born in 1950).

At the same time, it was suggested that the religious sphere needs to be strictly controlled by the state: «There must be a system, a control system. Because if Islam controls the Christians, they will not follow it and vice versa. It must be combined with each religion as the State Duma. I would create a council of religious representatives. If the state is not secular, we lag behind the world's societies. But it must be controlled. We can not give a way to Christianity, Islam, Buddhism or other religions. Something in common... Religion should be controlled, it can not be dissolved. If the Russian government created such a system, it would be easier to unite the Christians, the Muslims, the Buddhists and the other religions. They have to rely on something. And we do not have it, nothing. A lot of bad people use religion as a cover....» (male Azerbaijani, born in 1950).

During the studies of diasporas and migrant communities of the Republic of Tatarstan many leaders of migrant communities, as well as ordinary members of the diaspora, suggested that it is possible to solve social problems by 
regulating their life in society with religious norms. "The Bible and the Quran have small differences. Do not steal, do not kill, everything is the same. And what's the difference if Islam controls the society or the Bible. The main thing is that it should be correct. The main thing is not to use the Quran or the Bible for own purposes" (male Tajik, born in 1962).

The results of this study show that, in spite of the awareness of the majority of respondents of inability to establish religious orders of the state in today's realities, the number of people who support the idea that state policy and religious norms of communities should be united is large enough. Two-thirds of the respondents Azerbaijanis, a half of Tajik and a quarter of Uzbek respondents believe that their social life should be more or less governed by religious norms.

About $90 \%$ of Azerbaijanis and Uzbeks, two-thirds of Tajiks believe that the political system of Russia in some degree should comply with the principles of the religious state: "If a person didn't go to prison for theft, but lost his hand, he might not steal next time" (male Tajik, 27 years old).

Three-quarters of the Uzbek and a quarter of Azerbaijanis recognize that being in a difficult situation, they would prefer to be guided by their traditional norms, not the legal ones; about the third of Uzbek respondents and the oneseventh of Tajiks would prefer to be guided by religious norms.

One-third of Azerbaijanis and every second Tajik say that in a difficult situation they will be guided by the official Russian legislation.

The lack of confidence in the fact that a secular state can effectively solve political and social problems of society is truly important for young people. Among young people under 25 the number of those who support the strengthening of the role of religion in the life of state and society is several times higher than the number of respondents who support this position in other age groups.

A lot of researches are devoted to the causes and forms of employment of women, as well as its consequences and risks, which is connected with a change of place of residence and civil status. One of the difficulties connected with migration, the researchers pay particular attention to human trafficking, labor slavery, physical violence, humiliation and discrimination (Brednikova, 2003).

Since the migration, including labor migration, cannot be only legal, but also illegal / semi-legal, the study of this factor is complicated: a simple statistical calculation of the number of migrants and a description of their key sociodemographic characteristics (age, marital status, level of education, and others) is sometimes impossible (Chudinovskikh, 2004).

The number of migration flows is increasing, which can be viewed as a challenge for the host country, since migration is accompanied by a number of factors (for example, a higher proportion of informal employment, ethno-cultural practices) which may affect the structure of the host society.

\section{Conclusion}

The research of the structure of social identity of the respondents indicates that ethnic and religious identity is more important for young people under 25, whereas gender, family, status and professional characteristics are more important for the people of middle age, who are in the most active phase of their life cycle. Among all groups the greatest variety of social characteristics, indicating successful integration into the host society, was demonstrated by the Azerbaijanis. For them, the most important characteristic is the relevance of ethnic identity. A smaller set of social characteristics, the predominance of subjective characteristics over the objective structure of social identity, which is actual for the Tajik and Uzbek respondents demonstrate the problems of adaptation and weak integration into the host society.

Despite the comfortable inter-ethnic climate in the country (in general), the majority of respondents have no motivation for interethnic interaction. For the Tajiks and Uzbeks the barrier is the poor knowledge of the language. Azerbaijanis demonstrate a higher level of intra-group unity, which also prevents the integration into the host society. The respondents clearly express their focus on mononational marriages; the strong disapproval of interethnic marriage is expressed by the Uzbeks. Most respondents do not take any effort to integrate into the host community: it is demonstrated by a lack of desire to raise the level of the Russian language; unwillingness to go beyond their own ethnic community, etc.

The study has recorded a higher level of religiosity among younger respondents (under 25 y.o.). These are the respondents, who appreciate their level of competence and support the tightening of the religious regulations and prohibitions. This category of respondents can be characterized by the lack of confidence in a fact that a secular state can effectively solve political and social problems. Young people under 25 years old support the strengthening of the role of religion in a social life. At the same time, this category of respondents is characterized by the pursuit of a successful integration into the host community - in particular, young people are more likely to express the desire to improve the linguistic competence in Russian language. 


\section{Acknowledgments}

The work is performed according to the Russian Government Program of Competitive Growth of Kazan Federal University.

\section{References}

Abashin, S. (2007-2008). Ekonomicheskie migrant iz Tsentral'noy Azii: issledovanie transformatsii identichnosti, norm povedeniya i tipov sotsial'nikh svyazey Saint Petersburg: CISR.

Barth, F. (1989). Analysis of Culture in Complex Societies. Ethnos, 4, 120-142.

Berger, P.L. Lukman, T. (1995). The Social Construction of Reality: A Treatise on the Sociology of Knowledge. Academia-Center-Media. Brednikova, O. (2003). Dzenskaya trudovaya migratsiya: smena gendernykh kontaktov? Gendernye otnosheniya v sovremennoy Rossii. Samara: Samara University press.

Chudinovskikh, O. (2004). Prichiny i posledstviya krizisa Rossiyskoy migratsionnoy statistiki. Otechestvennye zapiski, 4, 176-190.

Gellner, E. (2009). Nations and Nationalism. Cornell University Press.

Hobsbawn, E. (1983). Invention of Tradition. Cambridge University Press.

Titova, T., Kozlov, V., Frolova, E. (2013). Diaspory i soobschestva migrantov v Respublike Tatarstan: etnosotsiologicheskie ocherki. Kazan: Mir bez granits. 